\title{
Bas Snelders. Identity and Christian-Muslim Interaction. Medieval Art of the Syrian Orthodox from the Mosul Area
}

\section{Christelle Jullien}

\section{(2) OpenEdition \\ 12 Journals \\ Édition électronique \\ URL : http://journals.openedition.org/abstractairanica/40885 \\ DOI : 10.4000/abstractairanica.40885 \\ ISSN : 1961-960X \\ Éditeur : \\ CNRS (UMR 7528 Mondes iraniens et indiens), Éditions de l'IFRI}

\section{Édition imprimée}

Date de publication : 1 décembre 2013

ISSN : 0240-8910

Référence électronique

Christelle Jullien, « Bas Snelders. Identity and Christian-Muslim Interaction. Medieval Art of the Syrian Orthodox from the Mosul Area », Abstracta Iranica [En ligne], Volume 32-33 | 2013, document 346, mis en ligne le 01 juillet 2016, consulté le 26 septembre 2020. URL : http://journals.openedition.org/ abstractairanica/40885; DOI : https://doi.org/10.4000/abstractairanica.40885

Ce document a été généré automatiquement le 26 septembre 2020.

Tous droits réservés 


\section{Bas Snelders. Identity and Christian- Muslim Interaction. Medieval Art of the Syrian Orthodox from the Mosul Area}

Christelle Jullien

\section{RÉFÉRENCE}

Bas Snelders. Identity and Christian-Muslim Interaction. Medieval Art of the Syrian Orthodox from the Mosul Area. Louvain, Peeters, 2009, XII-591 p. (Orientalia Lovaniensia Analecta 198)

1 Cette étude d'histoire de l'art montre avec acuité l'efflorescence d'un art chrétien qui se développa dans la région de Mossoul au XIII ${ }^{\mathrm{e}}$ s., et analyse ses relations d'influences avec l'art islamique à un moment où les conflits d'opposition entre communautés religieuses étaient alors assez fortes. L'A. montre comment l'appropriation d'éléments exogènes contribua à forger l'identité de la communauté syro-orthodoxe mossouliote, signe de son intégration et de son adaptation à son environnement musulman. 


\section{AUTEURS}

\section{CHRISTELLE JULLIEN}

CNRS, Mondes iranien et indien, Paris 